\title{
Assessing the Revenue Raising Capacity of the Local Government of Bongabon in the Philippines
}

\author{
Ana Liza M. Cruz \& Franz Jake M. Cruz \\ Municipality of Bongabon \\ Nueva Ecija, Philippines \\ Olive Chester Cuya-Antonio (Corresponding author) \\ Department of Public Administration
}

Nueva Ecija University of Science and Technology, Philippines

Received: July 11, 2018 Accepted: August 6, 2018 Online published: August 14, 2018

doi:10.5296/jpag.v8i3.13381ＵRL: https://doi.org/10.5296/jpag.v8i3.13381

\begin{abstract}
One source of funding for sub national government is imposition of taxes. It is imposed upon individual and corporation within the territorial jurisdiction of the municipality. Local governments are funded through Internal Revenue Allotment (IRA) provided by the National Government. The purpose of the study is to assess the local revenue generation capacity of the municipality of Bongabon, Nueva Ecija in the Philippines. The paper revealed that its calculated collection efficiency is only $20.6 \%$ of the total collectibles on Real Property Tax. The average local revenue raising capacity of the municipality of Bongabon, Nueva Ecija within the period of 7 years (2011 to 2017) is only $40.9 \%$ of the externally sourced revenue or IRA. The study concluded that the municipality of Bongabon, Nueva Ecija remains dependent on national government when it comes to funding. The study also identified various constraints to efficient tax collection while local citizens perceived the LGU capacity to collect tax negatively. More studies on tax capacity are encouraged to come up with sufficient baseline data that may serve as inputs to policy making and solve the problems of tax collection in the local level.
\end{abstract}

Keywords: local revenue, business tax, real property tax, bongabon, nueva ecija 


\section{Introduction}

\subsection{Background of the Study}

One of the most substantial sources of funding for every government all around the world is tax revenue. Taxes are charges imposed by the government on an individual or an organization to fund government expenditures. The governing body, throughout history, has used the amount collected through taxation to finance the operation of government (Simkovic, 2015). And there has been a role for taxation in the development process of local governments which are mainly ensuring sustainability and ownership (Mascagni et al., 2014).

Tax can either be direct or indirect taxes. Direct tax are charges imposed on an individual person or property (real property, personal property, etc.) directly, hence, the name "direct tax". It can also be defined or identified as taxes imposed on an individual that cannot be evaded or cannot be shifted or passed down to another. Direct taxes are taxes collected directly by the government from the taxpayer. On the other hand, indirect taxes are taxes collected by an intermediate party from the consumer which the intermediate party, ultimately, will file the tax return to the government. Indirect taxes include sales tax, value added tax (VAT), goods and services tax, and more. These taxes can be avoided when an individual does not avail the services or purchase of goods covered by indirect taxes. Hence, the success of the local governments to increase local revenues is dependent on its tax administration practices, but may likewise be influenced by some other factors which are beyond the range of control of the local government units (LGUs) (Manasan, 1995).

\subsection{Taxation in the Philippines}

Taxation in the Philippines is generally the same with the typical tax system of governments around the world. Various types of taxes are assigned to different levels of government. The central government levies taxes and collects the larger bulk of taxes like tariffs on imports, value added tax (VAT), income tax on individuals and corporations, alcoholic, tobacco and petroleum products tax, and the like. On the other hand, local governments are empowered by the central government to administer taxes, fees, and charges within their jurisdiction. According to a study done by the Asian Development Bank (2014), a sustainable and strong taxation system is a requirement of a good public administration. Local government units (LGU's) set these taxes are within the parameters provided by the central government and therefore have complete control on the taxes they levy (Book II, Section 129 of R. A. 7160).

Under Section 5, Article X of the Constitution of the Republic of the Philippines, power is bestowed upon the local governments to levy taxes, fees and charges. As the law states;

"Section5. Each local government unit shall have the power to create its own sources of revenues and to levy taxes, fees and charges subject to such guidelines and limitations as the Congress may provide, consistent with the basic policy of local autonomy. Such taxes, fees and charges shall accrue exclusively to the local governments."

The guidelines and limitations as well as the legal basis and parameters of taxing and revenue 
raising powers of the local governments are detailed in Republic Act No. 7160 otherwise known as the Local Government Code of 1991 (LGU Code). The revenue assignments of the local governments are largely fixed with maximum ceilings/rates (range) and are not yet inflation indexed. Tax rates can be adjusted only up to $10 \%$ once every 5 years. Tax rates require legislation. The real property tax basis is through a schedule of market values and is only subject to revisions/revaluations once every 3 years. These local revenue generation systems are not or cannot be subjected to review by the national/central government. Aside from levying taxes, charges and fees, the local government also has the power to grant tax exemptions, reliefs, penalties, and incentives. These benefits of decentralization and devolution of power, increases the capacity of the LGUs as well as reduce poverty despite the manifestations of weak governance (Troland, 2014).

Local government units derive their revenues from external and internal sources. The local governments receive shares from the central government taxes (Internal Revenue Allotment) mandated under the Section 6, Article X of the Constitution of the Philippines together with grants, special laws, borrowings and aides that all makes up the external sources. On the other hand, internal sources are tax revenues which include real property taxes, business taxes and non-tax revenues from government business operations proceeds from sales of government assets, and other fees and charges. The capacity of local governments to tap these financing sources either for infrastructure investment or delivery of basic services, contributes to faster economic growth and poverty reduction (De Vera \& Kim, 2003).

Real property taxes are collected by the provincial governments through the local government units. Since real properties cannot be moved and are visible, taxes on them have a high potential to increase local revenues (Marasigan, 2009). However, in the past few years, there are less than $60 \%$ of the total real property taxes collected.

Local business taxes, on the other hand, are taxes imposed on manufacturers, wholesalers, retailers, exporters and other business clusters. They are levied and collected by the municipalities and cities. The same with real property taxes, they have the potential to improve local government revenues. However, in practice, it is levied only on the declared annual gross receipts or sales accumulated by the business establishment in the preceding year. According to Marasigan (2009), the value of the total gross receipts or sales declared by the owner are difficult, if not, impossible to ascertain or confirm to be true". Good local taxes must be sufficient enough to generate ample revenues to financially support their own resources. In the Philippines, ratios of revenues coming from local sources to those coming from external sources reveal that local governments receive far greater subsidies from the national/central government than what they earn locally. The local government units are unable to tap their potential revenues because of inefficiency in revenue collection as well as tax gap ratios. This makes the LGU's somewhat IRA (internal revenue allotment) dependent.

The assessment will be done in the municipality of Bongabon, Nueva Ecija. Bongabon is a second-class town that can be found on the northeastern part of the province of Nueva Ecija. It is one of the 32 cities and municipalities of the province and is a boundary town of Nueva Ecija to the province of Aurora. The municipality Bongabon consists of 28 barangays and has 
a total population of more than 60,000 . The municipality's main source of income is agriculture with rice and vegetables like corn and onions as the main crops.

The municipal government of Bongabon is democratic in political set up. It consists of: the executive branch headed by the municipal mayor; the legislative body, responsible of making local laws and ordinances; and the third branch is the judicial branch or the Courts of Justice who interpret the ordinances. The three branches of the municipality coordinates and complements each other's functions toward local development (Gabriel, 2017)

Despite the importance of taxation for local development, little to no study has been conducted regarding the topic. This study will assess the revenue generation of the local government of the municipality of Bongabon, Nueva Ecija. While doing it, the revenue raising capacity as well as the revenue collection efficiency will be measured.

\subsection{Significance of the Study}

The study will be beneficial to Local Treasury Operation of Bongabon, Nueva Ecija in terms of determining the administrative capacity of LGU in raising local revenue sources. For taxation provides a potential beneficial effect in infrastructure building and good governance (Mascagni et al., 2014). The result of the study may be used as a tool to guide LGU-Bongabon in identifying the area of improvement and the significant problems and issues when it comes to raising revenues.

The assessment will identify the strengths and weaknesses of the local government revenue generation of the municipality. Thus, making it possible to mitigate, adjust, and improve on the lapses and deficiencies of the system while at the same time continue and take advantage on the strengths. This will result in a better and more improved overall revenue generation system of the local government of Bongabon, Nueva Ecija.

\subsection{Objectives of the Study}

Generally, the study aims at assessing the revenue raising capacity of the Local Government of the municipality of Bongabon, Nueva Ecija.

Specifically, the study aims to:

a) Describe the ordinances/resolutions passed/amended by the Sanggunian Bayan on local revenue raising;

b) To assess the capacity of the LGU in raising local revenue, and

c) To describe the taxpayers perception on the local revenue generation of the municipality.

d) Identify the constraints encountered by the municipality in the collection of taxes.

\section{Methodology}

The study used secondary data in so far as resolutions and ordinances related to taxation are passed and revised by the local legislative body of Bongabon, Nueva Ecija. The secondary data from the office of the Municipal Treasurer, office of the Assessor, and office of the local 


\section{Macrothink}

Journal of Public Administration and Governance

ISSN 2161-7104 2018, Vol. 8, No. 3

legislative body are subjected to analysis. Interviews and observations are used to collect data on the perceptions of town folks on the capacity of Local Government to generate income.

\subsection{Study Local}

The study local was in the municipality of Bongabon which can be found on the northeastern part of the province of Nueva Ecija in Central Luzon, Philippines.

\subsection{Analytical Framework}

This research is analyzed based on the framework conceptualized by the author and according to the literature reviews of this study.

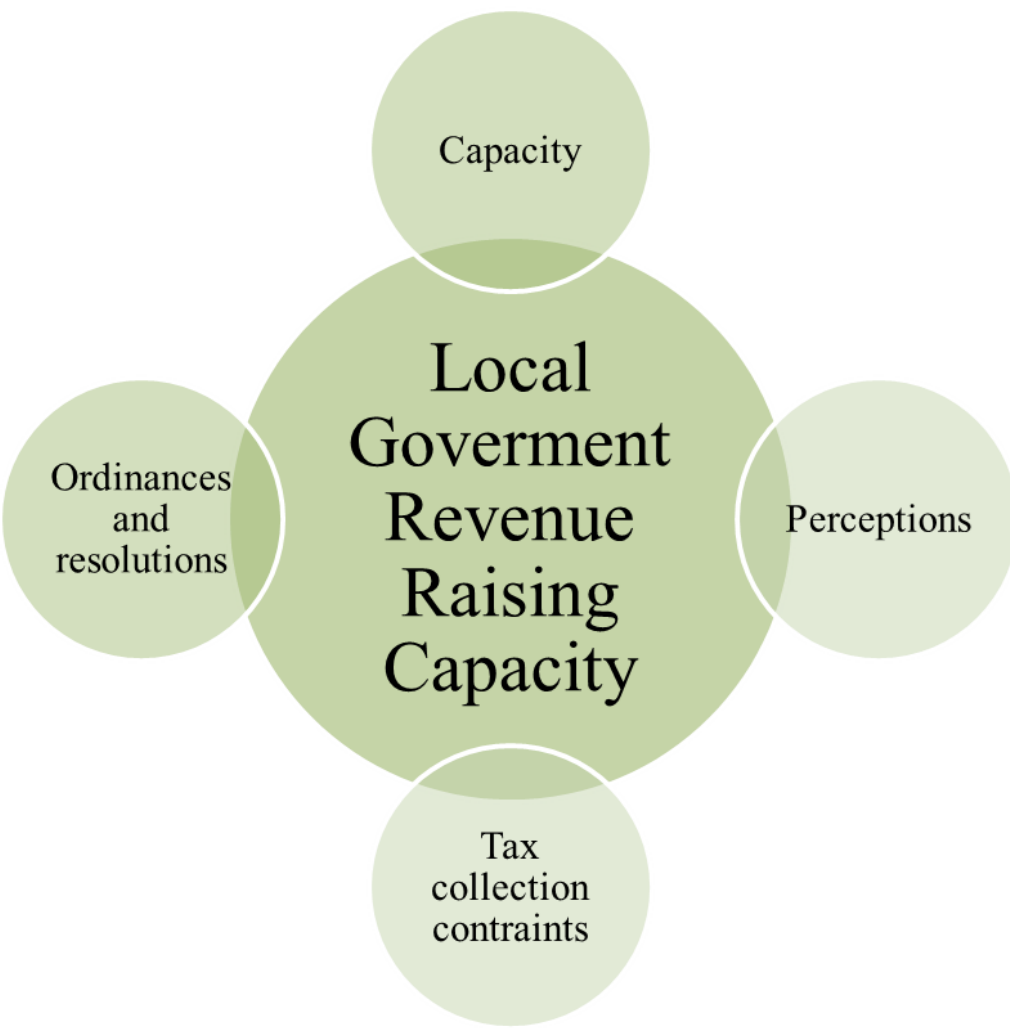

Figure 1. Research Paradigm.

The paradigm above was developed to show the factors that influences the local government revenue raising capacities of every LGUs. According to RA 7160 or the Local Government Code, the LGU has the following capacity and functions: to collect, and to create or update ordinances and resolutions that follows their spending trends. The local government raising capacity then is affected by tax collection constraints (Marasigan, 2009), and the taxpayers perception regarding the whole tax system of the LGU.

\subsection{Data Collection}

The study is designed to collect data using a combination of secondary data gathering and interviews. Secondary data will be collected from various government agencies and offices while data from interviews were from key informants. 


\subsection{Secondary Data Collection}

Data on the tax revenue, real property tax and business tax values, were gathered from secondary data sources like the Office of the Municipal Treasurer, Budget Officer and Assessor in the municipal hall of the municipality of Bongabon, Nueva Ecija. Secondary data on the ordinances/resolutions as well as the amendments done on them were also collected from the Office of the Sangguniang Bayan also in the municipality of Bongabon, Nueva Ecija.

\subsection{Interviews}

Key informants were chosen from business owners in the municipality of Bongabon, Nueva Ecija. Long-time business owners/operators were chosen to provide information on their perception of th municipal government capacity to raise revenue. Unstructured interview was employed to determine the levels of implementation of the ordinances/resolutions concerning tax revenue.

\subsection{Data Analysis}

Quantitative and qualitative mixed-method approach was used in this research. Qualitative research technique was employed through data collection, interviews, and data interpretations.

The quantitative part of the study is based on the research conducted by Maricar Mercader Marasigan entitled Why 'Good Local Taxes' aren't working?: Implication of the Revenue Assignment and Local Fiscal Environment to Revenue-Raising Capacity (The case of Local Governments in the Philippines). Marasigan's method used for calculating local governments' revenue raising capacity as well as their efficiency in collecting them will be used for this study.

The ratio of locally generated revenues to revenues coming from external sources determines the extent of the capability of the local governments to raise their own revenue. Along with the degree of their dependence to the externally sourced revenue using the following formula;

$$
\operatorname{Rev}_{\mathrm{Lg}}: \operatorname{Rev}_{\mathrm{Es}}
$$

Collection efficiency is calculated to assess the local government units' capacity to raise basic real property tax. It can be one of the parameters that LGU's may use in evaluating their tax administration and enforcement programs (USAID-GOLD Project, 2001). Collection efficiency is the ratio of revenue actually collected that comes from real property tax against revenue not collected. The ratio was computed by comparing a year's basic real property tax collection plus the discounts given to advance payments with the potential current year collectibles based on taxable assessed values (TAVs) of property in the LGU.

$$
\left(\mathrm{RPT}_{\text {Collected }}+\text { Discounts }\right): \text { Total Potential Collectibles }
$$

The total amount of uncollected real property tax for the current year represents the approximation of revenues foregone by the local government. Annual data of this can be used as a representation of the amount of efforts the local government does in order to implement 
the law and collect taxes.

\section{Results and Discussion}

\subsection{Ordinances and Resolutions on Local Revenue Raising}

The succeeding results and discussion are based on the existing ordinances and resolutions of the Municipality of Bongabon which are significant to the capacity of the LGU to raise its local revenue. The collections of municipal business and real property taxes from 2011 to 2017 were presented and based on it, the collection efficiency of the LGU was described.

\subsubsection{Business Tax}

Under the Municipal Revenue Code of the Municipality of Bongabon which was approved on November 4, 2013 and was effective on January 1, 2014, the impositions of taxes on the following were:
"On manufacturers, assemblers, re-packers, processors, brewers, distillers, rectifiers, and compounders or liquors, distilled spirits, and wines or manufacturers of any article of commerce of whatever kind or nature. In accordance to the following schedule:

Table 1. Tax rate per annum on commercial bodies listed above.

\begin{tabular}{c|c}
\hline $\begin{array}{c}\text { Amount of Gross Sales/Receipts for the } \\
\text { Preceding Calendar Year (Pesos) }\end{array}$ & Tax per Annum (Pesos) \\
\hline Less than 10,000 & 217.80 \\
\hline 10,000 or more but less than 15,000 & 290.40 \\
\hline 15,000 or more but less than 20,000 & 398.97 \\
\hline 20,000 or more but less than 30,000 & 580.80 \\
\hline 30,000 or more but less than 40,000 & 871.20 \\
\hline 40,000 or more but less than 50,000 & $1,089.00$ \\
\hline 50,000 or more but less than 75,000 & $1,742.40$ \\
\hline 75,000 or more but less than 100,000 & $2,178.00$ \\
\hline 100,000 or more but less than 150,000 & $2,904.00$ \\
\hline 150,000 or more but less than 200,000 & $3,630.00$ \\
\hline 200,000 or more but less than 300,000 & $5,082.00$ \\
\hline 300,000 or more but less than 500,000 & $7,260.00$ \\
\hline 500,000 or more but less than 750,000 & $10,560.00$ \\
\hline 750,000 or more but less than $1,000,000$ & $13,200.00$ \\
\hline $1,000,000$ or more but less than $2,000,000$ & $18,150.00$ \\
\hline $2,000,000$ or more but less than $3,000,000$ & $21,780.00$ \\
\hline $3,000,000$ or more but less than $4,000,000$ & $26,136.00$ \\
\hline $4,000,000$ or more but less than 5,000,000 & $30,492.00$ \\
\hline $5,000,000$ or more but less than $6,500,000$ & $32,175.00$ \\
\hline 6,500,000 or more & At a rate not exceeding forty five and thirty \\
\hline
\end{tabular}

"On wholesalers, distributors, or dealers in any article of commerce of whatever kind or nature in accordance with the following schedules:" 
Table 2. Tax rate per on commercial wholesalers, distributors, or dealers.

\begin{tabular}{l|c}
\hline \multicolumn{1}{c|}{$\begin{array}{c}\text { Gross Sales/Receipts for the Preceding } \\
\text { Calendar Year (Pesos) }\end{array}$} & Tax per Annum (Pesos) \\
\hline Less than 1,000 & 23.76 \\
\hline 1,000 or more but less than 2,000 & 43.56 \\
\hline 2,000 or more but less than 3,000 & 66.00 \\
\hline 3,000 or more but less than 4,000 & 95.04 \\
\hline 4,000 or more but less than 5,000 & 132.00 \\
\hline 5,000 or more but less than 6,000 & 159.72 \\
\hline 6,000 or more but less than 7,000 & 188.76 \\
\hline 7,000 or more but less than 8,000 & 217.80 \\
\hline 8,000 or more but less than 10,000 & 246.40 \\
\hline 10,000 or more but less than 15,000 & 290.40 \\
\hline 15,000 or more but less than 20,000 & 363.00 \\
\hline 20,000 or more but less than 30,000 & 435.60 \\
\hline 30,000 or more but less than 40,000 & 580.80 \\
\hline 40,000 or more but less than 50,000 & 871.20 \\
\hline 50,000 or more but less than 75,000 & $1,306.80$ \\
\hline 75,000 or more but less than 100,000 & $1,742.40$ \\
\hline 100,000 or more but less than 150,000 & $2,468.40$ \\
\hline 150,000 or more but less than 200,000 & $3,194.40$ \\
\hline 200,000 or more but less than 300,000 & $4,356.00$ \\
\hline 300,000 or more but less than 500,000 & $5,896.00$ \\
\hline 500,000 or more but less than 750,000 & $8,712.00$ \\
\hline 750,000 or more but less than $1,000,000$ & $10,648.00$ \\
\hline $1,000,000$ or more but less than $2,000,000$ & $12,100.00$ \\
\hline & At a rate not exceeding sixty point five percent \\
\hline
\end{tabular}

"On retailers:"

Table 3. Tax rate per annum of retailers

Gross Sales/Receipts for the Preceding Calendar Year (Pesos) 400000 or less More than 400000

Rate of Tax per Annum $2 \%$ $1 \%$

"On contractors and other independent contractors in accordance with the following schedule:"

Table 4. Tax rate per annum on contractors.

\begin{tabular}{c|c}
\hline $\begin{array}{c}\text { Gross Sales/Receipts for the Preceding } \\
\text { Calendar Year (Pesos) }\end{array}$ & Tax per Annum (Pesos) \\
\hline Less than 5,000 & 39.33 \\
\hline 5,000 or more but less than 10,000 & 88.44 \\
\hline 10,000 or more but less than 15,000 & 150.65 \\
\hline 15,000 or more but less than 20,000 & 237.77 \\
\hline 20,000 or more but less than 30,000 & 396.28 \\
\hline 30,000 or more but less than 40,000 & 551.49 \\
\hline 40,000 or more but less than 50,000 & $1,034.55$ \\
\hline 50,000 or more but less than 75,000 & $1,268.08$ \\
\hline 75,000 or more but less than 100,000 & $1,902.12$ \\
\hline 100,000 or more but less than 150,000 & $2,853.18$ \\
\hline 150,000 or more but less than 200,000 & $3,804.24$ \\
\hline
\end{tabular}


200,000 or more but less than 250,000

250,000 or more but less than 300,000

300,000 or more but less than 400,000

400,000 or more but less than 500,000

500,000 or more but less than 750,000

750,000 or more but less than $1,000,000$

$1,000,000$ or more but less than $2,000,000$

$2,000,000$ or more

The rates of taxes of the major kinds of businesses were provided above. Approved by the municipal councils and is implemented by the local chief executive of the municipality of Bongabon.

The total of the actual receipts collected from the businesses and the target annual income throughout the span of years 2011-2017 according to the records from the Municipal Treasurer's Office and the Municipal Budget Office which is shown on the table below.

Table 5. Business tax income target and actual amount collected from 2011-2017.

\begin{tabular}{c|c|c}
\hline YEAR & Income Target (Pesos) & Actual Receipts (Pesos) \\
\hline 2011 & 862000 & 1046881 \\
\hline 2012 & 750000 & 1011244 \\
\hline 2013 & 1081000 & 1142853.36 \\
\hline 2014 & 1221000 & 1597033.97 \\
\hline 2015 & 1190282 & 1931836.84 \\
\hline 2016 & 1477000 & 2179922.64 \\
\hline 2017 & 2125020.97 & 2415248.12 \\
\hline Average & 1243758 & 1621331 \\
\hline
\end{tabular}

The actual collection is slightly higher than the target value of the income for every year. The totals of the collection can be seen increasing annually, except for the year 2012, which is good because it is a sign of the continuing development of the municipality.

\subsubsection{Real Property Tax}

Real property taxes are levied by the provincial government but rely on the local government units particularly the municipalities that have jurisdictions on the said real property for its collection.

According to Villaroman (2017), the amount of tax levied on real properties can be computed by multiplying the "base value of the object or act" or the "fair market value of the property" being taxed upon by the fixed rate the law sets. In the case of the provinces, one percent $(1 \%)$ of the total assessed value of the real property will be the amount of tax to be paid for the year. The assessments were done by the Municipal Assessor's Office with provincial ordinances as guidelines for assessing which varies from different classifications of land (residential, mineral, agricultural, commercial or whatever the case may be on the municipalities.

The municipality of Bongabon is among those that are tasked to collect these taxes and the total actual receipts as well as the total potential collectibles from the year 2011 to 2017 are shown in the following table. 
Table 6. Real property tax potential collectibles and actual amount collected from 2011-2017.

\begin{tabular}{c|c|c}
\hline YEAR & $\begin{array}{c}\text { Total Potential Collectibles } \\
\text { (Peso) }\end{array}$ & Actual Receipts (Peso) \\
\hline 2011 & 11319245.80 & 2295241.92 \\
\hline 2012 & 23862082.40 & 3822317.14 \\
\hline 2013 & 24908249.20 & 3445317.00 \\
\hline 2014 & 25739505.00 & 4830533.90 \\
\hline 2015 & 26323892.00 & 5334200.14 \\
\hline 2016 & 26687268.80 & 6222014.26 \\
\hline 2017 & 24692130.00 & 7688579.88 \\
\hline Average & 23361767.60 & 4805457.75 \\
\hline
\end{tabular}

The table shows that there is a massive increase in the target amount of income collected from real property taxes annually from 2011. At the same time, the actual receipts coming in from the collection of real property taxes have also skyrocketed. With that being said, the actual collections, however, are far from hitting the target income which poses as a huge problem in the revenue generation of local government units.

\subsubsection{Collection Efficiency}

Efficiency in the collection or implementation of taxes can be measured using different methods. Among them, the one used in this study, is by calculating the ratio of revenue actually collected or the total of the actual receipts of real property taxes to total real property tax revenue not collected. Using the formula below, the efficiency can be yielded.

$$
\left(\mathrm{RPT}_{\text {Collected }}+\text { Discounts }\right): \text { Total Potential Collectibles }
$$

The value for real property tax actually collected to be used for this study is the average of the years wherein data were collected, in this case, 2011-2017. Whilst the total potential collectibles will be the average income target for real property tax for the period of 2011-2017.

\subsection{4 : 163532373.20}

\subsection{4 or $20.5697524 \%$}

The calculated efficiency is that only $20.5697524 \%$ of the total collectibles are collected which means almost $80 \%$ are not. Almost $20 \%$ efficiency is very low and there might be a problem on either the administration of the law or the implementation of it. Another possible problem is that the low levels of initiative of the taxpayers to pay what they owe to the government.

\subsection{Local Revenue Raising Capacity}

Local revenue raising capacity of a local government unit can be measured or calculated using the ratio of revenue from internal sources to outside sources revenue. This formula can measure the capability or the dependency of the local government to the national government or the Internal Revenue Allotment (IRA).

$$
\operatorname{Rev}_{\mathrm{Lg}}: \operatorname{Rev}_{\mathrm{Es}}
$$


The average value of locally generated revenue as well as revenue coming from external sources annually for the years 2011 to 2017 were used to show the capability to raise local revenue or dependency on IRA of the municipality of Bongabon, Nueva Ecija.

\section{$44987521.24: 110084613$}

\section{$\mathbf{0 . 4 0 8 6 6 3 1}$ or $\mathbf{4 0 . 8 6 6 3 1 \%}$}

The average local revenue raising capacity of the municipality of Bongabon, Nueva Ecija throughout seven years (2011 to 2017) is only $40.866 \%$ of the externally sourced revenue or the Internal Revenue Allotment (IRA). This confirms the dependency of municipality to the financial transfer from the national government. The local government of Bongabon, Nueva Ecija is unable to raise the revenue from local sources to fund their own expenditure.

\subsection{Taxpayers'Perceptions}

Interviews were done on key informants that include business owners and/or operators. Businesses that have been paying taxes for a long time were identified and were interviewed for this study. A total of 29 business owners and/or operators were interviewed with guide questions as to how they pay their business taxes and what is the level of implementation of the Municipal Revenue Code in terms of business tax collection.

Almost all of the respondents paid their taxes this year (C.Y. 2017) with an exemption of 1 who declined to answer. Of the 28 respondents only 17 of them paid their taxes within the allowable period (until the 20th day of January). This must be one of the major reasons for cases of condonation of interests and/or penalties, as well as the extension of payment deadlines without penalties.

Out of the 29 interviewed, $62 \%$ of them (18 people) have comparable response. They have said that for the past few years, the levels of implementation of the Municipal Revenue Code or the collection of business tax were not that great compared to the collection in the last two years.

Respondents also said that there is an improvement regarding the collection of business tax that the municipality levies. This is evident that collection of taxes is becoming more efficient, thus, the target income of the LGU can be achieved.

Taxpayers who tend to not pay their taxes are mainly due to the bloated interest and penalties imposed upon their original tax amount according to the respondents. This drives them to be delinquent taxpayers and rely on the condonation of their tax penalties and interest which is contrary to the law. The law requires that unless the real property tax, surcharges and penalties are paid before the expiration of the year for which the tax is due, except when the notice of assessment or special levy is contested administratively or judicially, the delinquent real property will be sold at public auction (R.A. 7160, 1991). 


\subsection{Constraints of Revenue Raising of Bongabon}

There are a few hurdles or constraints that the municipality is facing regarding revenue generation, the administrative, legal and political constraints. The municipal revenue code that encompass business taxes can only be revised once every five (5) years and on real property taxes once every three (3) years. Since the approval of the Local Government Code (R.A. 7160) in 1991, the Municipal Revenue Code of the municipality of Bongabon, Nueva Ecija has only been revised a few times. The same also applies to the Provincial Revenue Code which contains real property tax rates which, according to Villaroman (2017), revisions are "hardly observed and the schedules are outdated".

For that long period of the revenue code with few revisions made, the rates might not be appropriate for the current time. The lawmakers do not find time to revise the code according to its period of revision. There are even cases that they extend the payment deadlines which are clearly a political factor. This is to avoid the negative feedbacks of the public and for the next election season politicians would still earn their votes. However, this is the government promoting procrastination and irresponsibility to the taxpayers.

Substantiate to this administrative, political and legal constraints are the issuance of various policies from the provincial government allowing the condonation of interests and penalties on real property taxes. These are Resolution No. 47-s-2012 issued on February 27, 2012, Resolution No. 161-s-2011 issued on July 11, 2011, and the most recent Resolution No. 387-s-2017 issued only last September 2017. These resolutions grant the implementation of the schedule of base unit market values for General Revision of Real Property Assessment in the Province of Nueva Ecija, wherein it can be noticed that the prescribed period of every three (3) years was not followed. The schedules of deadlines of the payment of business taxes, on the other hand, were also extended by resolutions of the municipal government. Among them are Resolution No. 101-s-2012, Resolution No. 24-S-2014, and Resolution No. 28-S-2016 which all provided extensions of deadlines.

Another possible constraint is the compliance of the taxpayers to pay their taxes. People more often do not have initiatives when it comes to paying taxes. They want to pay their taxes only because of incentives. This is due to Resolution No. 34-s-2015, Provincial Ordinance No. 3-s-2015, Collection of Real Property Tax, Section 2A. 56. It provides for tax discounts for advance and prompt payments (10\% and $20 \%$ discount in prompt and advance respectively).

People are not afraid to violate the policies and incur penalties because the government is too lenient to them. As concrete proof, the Municipal Revenue Code (Ordinance No. 125-s-2013) of Bongabon states that taxes not paid within the first twenty (20) days of January of every year will charge an additional late payment of twenty-five percent $(25 \%)$ of the original amount of business tax due, and in the case of unpaid real property taxes the interest of $2 \%$ every month from the due date but not exceeding 36 months. If the taxes due continues to be unpaid, the said penalties will be enforced to them, but because it is their responsibility as law abiding citizens so they have to pay for it. Clearly, this shows that policies are meant to be violated or abused. 


\section{Conclusion and Recommendations}

The municipality of Bongabon is far from independency from the national government when it comes to local revenue raising. This is mainly because of the lack of ability of the LGU to raise local revenue from sources such as business tax and real property tax. Bongabon only has an average of $40.866 \%$ in its local revenue raising capacity and has approximately $20.6 \%$ efficiency ratio which is very low.

Based on the results, there is a need for the government to establish programs that would encourage taxpayers to pay their taxes on time or in advance. The extension of deadlines for tax payments of business taxes is like a double-edged sword. It promotes the negative behavior of procrastination but at the same time, it can be a positive driving force to encourage taxpayers to pay due to the waived penalties.

With so many constraints in local revenue raising, it is hard to achieve total independency of the LGUs from the national budget share or the IRA. It can only be achieved through good governance and strict implementation of the law. We can only look into the positive side of decentralization and devolution of power to the local government. The degree of fiscal autonomy given to the LGUs is for the benefit of the people at the grassroots level and would contribute to economic growth and poverty reduction.

Another concern is the political constraints that may happen. Politics is a powerful tool and can definitely affect the administration and implementation of laws regarding local revenue generation. With this in mind, political concerns must be put aside first and implement the law the way it is. One more possibility in the improvement of the overall tax system of local governments is the calculation of effective tax rates specific to every local government unit (King \& Fullerton, 1984).

Despite all the constraints on revenue raising, it is apparent that what is written on the law must be implemented. This will create a sense of responsibility to people to abide by these national and local policies, in this case, taxpaying.

There is a need to create and implement laws and we must follow every bit of it. It is for the benefit of the people that policies are enacted, but having more of them makes it a lot more difficult to implement them. The lawmakers need to focus on existing policies, its improvement and strict implementation instead of creating other laws that are usually a canopy of the same law.

Generally, the law defines the government and its people. As citizens of this nation, we are bound to obey the law and we have freedom to question it if there is an act of omission or commission as far as obeying the law is concerned. This is a trait of a strong democratic government. In the case of local revenue policies, the government and the people need to understand that taxes are the fuel of the nation. Our government, hence, our nation will not be able to operate without taxes. So paying right taxes is every citizen's responsibility.

For future researchers, the limitations of this study are the respondents' number and the profiles of the respondents. They might consider having a larger number of respondents or 
compare the data of different municipalities, as well as consider taxpayers from different sectors. This would add more depth to the study and might lead to a different result.

Researchers may also consider the following topics related to this study, such as determining the positive and negative effects of fiscal autonomy of the LGUs, evaluating the awareness of the public on the benefits of taxes, and assessing the level of implementation of the LGUs in local revenue collection. With these, more baselines can be established as it promotes the responsiveness of the people and may contribute as inputs to the field of policy making and in solving the problems of tax collection in the local level.

\section{References}

Asian Development Bank. (2014). A comparative analysis of tax administration in Asia and the Pacific. Mandaluyong City, Philippines: Asian Development Bank

De Vera, R., \& Kim, Y. H. (2003). Local Government Finance, Private Resources, and Local Credit Markets in Asia, ERD Working Paper Series, 46, Asian Development Bank

Gabriel, A. G. (2017). Transparency and accountability in local government: levels of commitment of municipal councillors in Bongabon in the Philippines, Asia Pacific Journal of Public Administration, 39(3), 217-223. https://doi.org/10.1080/23276665.2017.1368902

King, M. A., \& Fullerton, D. (1984). The Theoretical Framework. In King, MA \& Fullerton, D. (eds.) The Taxation of Income from Capital: A comparative study of the United States and the United Kingdom, Sweden and Germany (pp. 7-30). Chicago, Illinois, USA: University of Chicago Press

Lim, D. (1983). Instability of Government Revenue and Expenditure in Less Developed Countries. World Development, 11(5). https://doi.org/10.1016/0305-750X(83)90078-5

Manasan, R. G. (1995). Revenue Mobilization in Local Government Units: The Early Years of Local Government Code Implementation. Philippine Institute for Developmental Studies (PIDS). 95-02

Marasigan, M. M. (2009). Why 'Good Local Taxes' Aren't Working? Implications of the Revenue Assignment and Local Fiscal Environment to Revenue Raising Capacity (The Case of Local Governments in the Philippines). The Hague, The Netherlands.

Mascagni, G., Moore, M., \& Mccluskey, R. (2014). Tax Revenue Mobilization in Developing Countries: Issues and Challenges. Belgium: European Union.

Municipal Revenue Code of the Municipality of Bongabon, Nueva Ecija. (2013). Ordinance No. 125-s-2013

National Tax Research Center. (2016). Guide to Philippine Taxes. Chapter XI (Local Taxes). Department of Finance, Republic of the Philippines.

Provincial Revenue Code of the Province of Nueva Ecija. (2015). Provincial Ordinance No. 03-s-2015. Collection of Real Property Tax. Resolution No. 34-s-2015 
Republic Act No. 7160 (R.A. 7160). Local Government Code of 1991.

Simkovic, M. (2015). The Knowledge Tax. 82 Chicago Law Review 1981. https://doi.org/10.2139/ssrn.2551567

The 1987 Constitution of the Republic of the Philippines. Article X

Troland, E. (2014). Can Fiscal Transfers Increase Local Revenue Collection? Evidence From The Philippines. Job Market Paper. University of California, San Diego

Villaroman, L. (2017). Factors Affecting Collection of Real Property Tax in the Provincial Treasurer's Office of Nueva Ecija (December 24, 2017). https://doi.org/10.2139/ssrn.3093130

\section{Copyright Disclaimer}

Copyright for this article is retained by the author(s), with first publication rights granted to the journal.

This is an open-access article distributed under the terms and conditions of the Creative Commons Attribution license (http://creativecommons.org/licenses/by/4.0/). 